\title{
A Simplified Approach to Pollutant Load Modeling
}

\author{
Mark Pribak $^{1}$ and Justin Siegrist ${ }^{2}$ \\ ${ }^{1}$ Wade Trim, Detroit, Michigan; ${ }^{2}$ Wade Trim, Cincinnati, Ohio. \\ Received 201404 01, accepted 201501 16, published 20150220.
}

\begin{abstract}
The combined sewer overflow (CSO) control requirements imposed by the United States Environmental Protection Agency (USEPA) on approximately 1100 sewer district utilities within the United States initially focused solely on the volumetric reduction of CSOs, with the assumption that a corresponding reduction in pollutant loads to a combined sewer system's (CSS) receiving stream would result. As the development of CSO long term control plans for addressing the agency's CSO control policies has progressed, the focus of CSO control has shifted, and assessing water quality benefits through quantitative analysis is becoming more common.

Development of CSO improvements typically involves the consideration of several alternatives, and the benefits provided by each are evaluated in addition to its cost. While evaluating CSO control alternatives in Cincinnati, Ohio a simplified approach for comparing the relative water quality benefits achieved by each alternative was developed. Pollutant load event mean concentrations (EMCs) were developed for the pollutants of concern, based on available national average information. Within the existing conditions and alternatives models being evaluated utilizing USEPA's Stormwater Management Model 5 (SWMM5), EMC assignments were applied to the rainfall derived infiltration and inflow, sanitary baseflow and individual subareas based on land use characteristics. The treatment effectiveness of both grey and green CSO and stormwater treatment facilities were simulated using estimated pollutant removal efficiencies. A single design storm event as well as continuous annual simulation modeling over an entire year was performed using design storm rainfall and historical rainfall data. Pollutant loadings to the receiving stream were quantified and compared to assess the water quality benefit of each alternative. This study presents these results and provides an approach for making relative comparisons of the water quality benefits offered by CSO control alternatives within any CSS.
\end{abstract}

Keywords: water quality, pollutant removal, sustainable infrastructure, combined sewer overflow, stormwater management.

\section{Introduction}

The study area, known as the Upper Duck watershed, is a 3700 acre (1 497 ha) combined sewershed located in Cincinnati, Ohio. The collection and conveyance sewer system (system) for the sewershed currently discharges a volumetric quantity of combined sewer overflow (CSO) to Upper Duck Creek, its receiving stream (stream), that is noncompliant with the U.S. Environmental Protection Agency's (USEPA) CSO control requirements. To address this, several CSO improvement alternative scenarios (alternatives) were developed with the intent of volumetrically controlling $\geq 85 \%$ of the annual wet weather CSO influent to the CSO regulators throughout the sewer system, in accordance with the USEPA's CSO control requirements.

The analysis of these alternatives initially focused on reductions in overall CSO volume to the stream, with the recognition that reducing CSO volume will have a corresponding reduction in pollutant load and water quality benefit. Although the CSO control guidelines established for the Metropolitan Sewer District of Greater Cincinnati (District) by the governing document known as the Final Wet Weather Improvement Program (MSDGC 2009) specify CSO reductions to the stream from a volumetric standpoint only, the District requested that a separate analysis specifically focused on water quality be performed.

The purpose of this analysis was to provide a relative comparison of the performance of each alternative regarding pollutant load reductions to the stream when compared to the system's current pollutant load contribution, which is referred to as existing conditions. The results would be considered within an alternatives evaluation process for use in selecting a preferred alternative. This study describes the alternatives that were considered, along with the assumptions that were made during the development of the pollutant load models for the existing conditions and alternatives scenarios using SWMM5.

Pribak, M. and J. Siegrist. 2015. "A Simplified Approach to Pollutant Load Modeling." Journal of Water Management Modeling C387. doi: 10.14796/JWMM.C387.

(c) CHI 2015 www.chijournal.org ISSN: 2292-6062 


\section{CSO Improvement Alternatives}

Each alternative was developed to meet the $85 \%$ volumetric control requirement where control is defined as providing treatment of the influent wet weather CSO to a given CSO regulator. Treatment was defined as each or any combination of green or grey CSO treatment infrastructures. The green infrastructure implemented for this study was defined by the District as any approach that utilized what they considered to be a sustainable solution, which in this case is stormwater removal and source control. For the District, sewer separation qualified as green infrastructure because it provides removal of stormwater from the CSS and reduces overflows. Also for the District, stormwater detention ponds and bioretention basins and cells that are installed in the watershed upstream of the CSS runoff collection points (to capture stormwater runoff and release the captured flow back to the CSS at a lower, controlled rate to reduce overflow at the downstream regulator) also qualify as green infrastructure because the basins provide source control. Stormwater wetlands that are used to provide treatment of separated stormwater also qualify as green infrastructure. The grey infrastructure implemented for this study was defined as conveying CSO to the downstream wastewater treatment plant (WWTP), capturing and storing CSO in a holding tank and treating CSO with an enhanced high rate treatment (EHRT) facility. For this study, the alternatives developed consisted of a proposed grey infrastructure, green infrastructure and hybrid solution. The components of the existing conditions and alternatives scenarios are provided in the following sections. (A summary comparison of the components within each alternative is provided in Table 1 in section 2.5.)

\subsection{Existing Conditions}

Existing conditions are representative of the system's baseline of pollutant load being delivered to the stream as a result of wet weather overflows and stormwater runoff contributions.

\subsection{Grey Alternative}

This alternative maximized grey infrastructure and relied heavily on end-of-pipe solutions, consisting of an increased underflow contribution to the WWTP, an EHRT and a storage tank. Minimal green infrastructure was implemented for this alternative.

\subsection{Green Alternative}

This alternative maximized green infrastructure to offload stormwater from the system through sewer separation or source control detention, and eliminated the need for end-of-pipe storage or treatment facilities. Unfortunately, an alternative that fully depended on these strategies alone to eliminate all end-of-pipe facilities was determined not to be feasible given the characteristics of the watershed. However, because of the increased reliance on green infrastructure for this alternative, the end-of-pipe facilities needed to achieve CSO control compliance were significantly downsized.

\subsection{Hybrid Alternative}

This alternative identified a combination of the most cost effective green infrastructure that maximized community benefits in addition to the use of end-of-pipe facilities.

\subsection{Summary and Comparison of Alternatives}

Table 1 provides a summary of the main components of each alternative

Table 1 Alternatives pollutant removal infrastructure components summary.

\begin{tabular}{lccc}
\hline \multicolumn{1}{c}{ Infrastructure } & Grey Alternative & Green Alternative & Hybrid Alternative \\
\hline Regulator Capacity Increase (MGD) & 11 & 7.8 & 9 \\
EHRT Treatment Capacity (MGD) & 100 & 42 & 95 \\
Storage Tank Size (MG) & 1.2 & 0.7 & 0.7 \\
Separation Area (Acres & 0 & 945 & 316 \\
\hline
\end{tabular}

\section{Pollutant Load Model Development}

The pollutant load model was developed using the most recently calibrated SWMM5 representation of the system (Wade Trim, Inc. and XCG Consultants, Inc. 2012). The updated model was used to represent the existing conditions and the alternatives that were being considered for CSO control improvements. These models were modified to include the calculation of pollutant loading and estimated pollutant removal resulting from the proposed stormwater and CSO treatment features within each alternative. This section presents a description of the pollutants modeled, sources, loading generation approach and pollutant removal approach.

\subsection{Pollutants Modeled}

The stream's total maximum daily loads (TMDL) report (OEPA 2010), developed by the Ohio Environmental Protection Agency, specified total suspended solids (TSS) and $5 \mathrm{~d}$ carbonaceous biochemical oxygen demand $\left(\mathrm{CBOD}_{5}\right)$ as the pollutants of concern within the system's watershed. The analysis therefore focused on the water quality benefits achieved for these parameters.

\subsection{Pollutant Sources}

Pollutants are generated in the stream's tributary watershed and sewershed from multiple sources including sanitary sewage, surface runoff and rainfall derived infiltration and inflow (RDII) that are conveyed through either sanitary, stormwater or combined sewer pipes. Each of these sources typically generates pollutants at different concentrations. For the TSS and $\mathrm{CBOD}_{5}$ pollutants being considered for this study, dry weather sanitary sewage typically has the highest average concentrations, while surface runoff and RDII typically have lower concentrations. The pollutant load models were developed such that each pollutant was independently loaded from each source to account for the variations in pollutant concentration. 


\subsection{Pollutant Loading Approach}

\section{General}

Pollutant concentrations in wet weather flows typically vary over time both during an event and between events based on a number of factors which leads to variations in the magnitude of pollutant loads. These variations in concentration are typically a result of two primary factors. First, the buildup of pollutants on surface areas or within the sewer system between storm events. Second, the subsequent washoff of these pollutants during a storm event. Because of these buildup and washoff conditions, wet weather flows from a storm event occurring after a long dry period can be expected to have higher pollutant concentrations than storms occurring during a particularly wet period. Pollutant concentrations can also vary temporally over the duration of an event, which is also due to the buildup and washoff phenomena. The washoff of builtup pollutants at the beginning of an event contains a disproportionately higher concentration than at the end of that same event. This is commonly referred to as the first flush effect.

In order to simulate the buildup and washoff characteristics of pollutants in a model, it is necessary to have a robust field sampling dataset from the watershed being studied to understand the expected rates of buildup and washoff. This dataset was unavailable for this particular watershed, and so the pollutant loading model for the stream was developed based on event mean concentrations (EMCs) that assume a constant pollutant concentration when generated by the pollutant source for all flows and storm conditions. Furthermore, because of the simplified EMC approach for pollutant loading, the pollutant concentration does not vary or decay as it travels through the system, as might be expected with typical fate and transport of pollutants. Because this study was to be used as a planning level relative comparison, the simplified EMC approach for pollutant loadings was acceptable.

Although the pollutant load model uses a simplified approach of assuming an EMC for each pollutant, the model does track variations in pollutant concentration based on its source. TSS data was readily available for most pollutant sources.
$\mathrm{CBOD}_{5}$, however, contained data gaps pertaining to stormwater runoff concentrations. Based on a review of historical data from a local WWTP (Jenkins 2011), a study of the relationship of the raw wastewater $\mathrm{BOD}_{5}: \mathrm{CBOD}_{5}$ ratio (Muirhead et al. 2006), and application of engineering judgment based on experience, it was assumed that $\mathrm{CBOD}_{5}$ was equal to $80 \%$ of $\mathrm{BOD}_{5}$ values and thus a factor of 0.8 was applied to the $\mathrm{BOD}_{5}$ concentration data that was available. Below is a separate discussion describing the development of each pollutant load's EMC for each source.

\section{Sanitary Base Flow}

Sanitary sewage flow rates in a combined sewer system account for a relatively small fraction of the total flow when compared to the larger flows generated during storm events. Although these sanitary flow rates are small, for this study area the base flow has been observed to have considerably higher pollutant concentrations that will impact the overall pollutant load as it is diluted by stormwater. During the peak of large storm events, the dilution ratio of sanitary sewage to stormwater is such that the sanitary pollutants have a negligible influence on the pollutant concentration. However, during small events and at the tail end of large events, the dilution ratio is much smaller, allowing the sanitary sewer pollutants to have a noticeable impact on pollutant concentration.

Selection of EMCs for sanitary sewage was based on monitoring data collected at a local WWTP. Data for TSS and $\mathrm{CBOD}_{5}$ was reported for both wet weather and dry weather flow conditions. As expected, there was an inverse relationship between flow and pollutant concentration due to the dilution of sanitary sewage into stormwater during storm events. To isolate the pollutant concentration of the sanitary component, samples collected during dry weather periods were evaluated. According to the sampling data, the maximum influent flow rate experienced at the Little Miami WWTP was 81 MGD (3.55 m³/s), while the minimum was $15 \mathrm{MGD}\left(0.66 \mathrm{~m}^{3} / \mathrm{s}\right)$. After evaluating the data, it was assumed that influent flow below $18 \mathrm{MGD}\left(0.79 \mathrm{~m}^{3} / \mathrm{s}\right)$ corresponded generally to dry weather flow conditions. The samples collected during such low flow periods were used to calculate

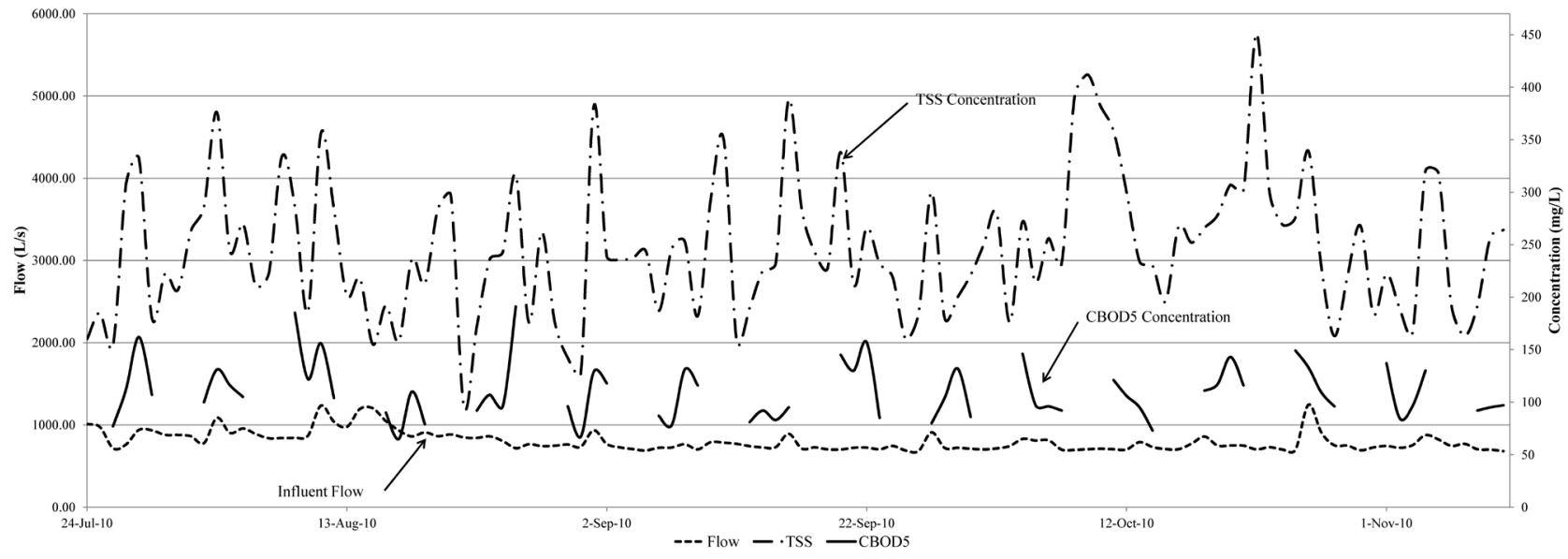

Figure 1 Data subset of local WWTP influent pollutant concentrations during dry weather flow. 
average pollutant concentrations. Figure 1 above shows an example subset of this data in a continuous plot of flow, TSS and $\mathrm{CBOD}_{5}$ over time. This plot depicts the period of dry weather flow that was used to isolate the dry weather pollutant concentrations. The final average pollutant loads for TSS and CBOD 5 are shown in Table 2.

Table 2 Sanitary base flow pollutant concentrations.

\begin{tabular}{lcc}
\hline \multicolumn{1}{c}{ Source } & $\mathrm{TSS}(\mathrm{mg} / \mathrm{L})$ & $\mathrm{CBOD}_{5}(\mathrm{mg} / \mathrm{L})$ \\
\hline $\begin{array}{l}\text { Sanitary base flow using local WWTP flow data } \\
\text { during period of influent dry weather flow }\end{array}$ & 230 & 100 \\
\hline
\end{tabular}

\section{Stormwater Runoff}

Stormwater runoff contributes pollutant loads to the stream through two separate flow paths. In areas tributary to a storm sewer, surface runoff is diverted directly to the stream either via sheet flow, open channel drains or storm sewer outfalls. Storm flow may pass through a stormwater detention pond. In combined sewer areas, surface runoff enters the combined sewer system through inlets and comingles with sanitary sewage. This combined flow is transported through the collection system to a CSO regulator. At the regulator, flow rates exceeding that regulator's capacity are split with a portion of the flow going to the downstream WWTP and the remaining flow discharging to the stream via the outfall.

Stormwater load concentrations from the watershed's surface runoff in combined and separated storm sewer areas are generated through an identical mechanism regardless of their source of origin. Variations in specific pollutant load concentrations are dependent on the individual land use makeup of each subarea. Variations in land use between subareas generate corresponding variations in pollutant load concentrations.

Standard EMC values for the watershed had not been developed. For this reason, multiple references for selection of stormwater EMC values were reviewed for use as input to the pollutant load models. These references included previous studies performed for the watershed, literature values, and the national stormwater quality database. Each had differing degrees of detail for specifying load concentrations. Table 3 illustrates the range of load concentrations from each reference.

Table 3 Stormwater pollutant concentrations various references.

\begin{tabular}{lcc}
\hline \multicolumn{1}{c}{ Source of Data } & TSS $(\mathrm{mg} / \mathrm{L})$ & CBOD $_{5}(\mathrm{mg} / \mathrm{L})$ \\
\hline National Stormwater Quality Database $(\mathrm{v} \mathrm{1.1,2005)}$ & 17 to 99 & 5.4 to 11.0 \\
Stormwater BMP and Detention (Stahre and Urbonas 1993) & 100 & 9 \\
\hline
\end{tabular}

Final pollutant concentrations for stormwater runoff were based on the information from the National Stormwater Quality Database (NSQD) version 1.1, 2005 (Maestre and Pitt 2005). The NSQD provided the most detail by specifying separate load concentrations for each land use category. This database was developed by the Center for Watershed Protection and the University of Alabama. The median pollutant concentration values documented in this database were based on data collected from
200 municipalities across the country over a 10 y period. Median pollutant concentrations identified in the NSQD for various land use types are shown in Table 4. It should be noted that $\mathrm{CBOD}_{5}$ values are not reported in the NSQD. For this reason, it was assumed that $\mathrm{CBOD}_{5}$ was equal to $80 \%$ of $\mathrm{BOD}_{5}$ values based on a review of historical data from the local WWTP (Jenkins 2011), a study of the relationship of the raw wastewater $\mathrm{BOD}_{5}: \mathrm{CBOD}_{5}$ ratio (Muirhead et al. 2006) and applying engineering judgment based on experience. For this study, it was proposed to combine available land use data with EMCs to develop load inputs for each tributary area.

Table 4 Median pollutant concentrations.

\begin{tabular}{lccc}
\hline \multicolumn{1}{c}{ Land Use Description } & $\mathrm{TSS}(\mathrm{mg} / \mathrm{L})$ & $\mathrm{BOD}_{5}^{(1)}(\mathrm{mg} / \mathrm{L})$ & $\mathrm{CBOD}_{5}^{(2)}(\mathrm{mg} / \mathrm{L})$ \\
\hline Residential & 49.0 & 9.0 & 7.2 \\
Mixed Residential & 66.0 & 7.8 & - \\
Commercial & 43.0 & 11.0 & 8.8 \\
Mixed Commercial & 54.5 & 9.0 & - \\
Industrial & 81.0 & 9.0 & 7.2 \\
Mixed Industrial & 82.0 & 7.5 & - \\
Institutional & 17.0 & 8.5 & 6.8 \\
Freeways & 99.0 & 8.0 & - \\
Mixed Freeways & 88.0 & 8.2 & - \\
Open Space & 48.5 & 5.4 & 4.3 \\
Mixed Open Space & 78.0 & 6.0 & - \\
(1) Source: NSQD (v 1.1, 2005). & & &
\end{tabular}

(1) Source: NSQD (v 1.1, 2005).

(2) Developed assuming $80 \%$ of BOD5 values.

The geographical information system (GIS) database for the study area's watershed included classification of land use for over seventeen land use types. Based on similarities, these GIS land use classifications were consolidated into four basic land use categories as shown in Table 5. These four consolidated land use categories were selected based on identifying similar land use categories as presented in the NSQD. Table 6 provides a summary of the land use area distribution within the watershed.

Table 5 Consolidated land use categories used for water quality models.

\begin{tabular}{lll}
\hline \multicolumn{1}{c}{ Land Use Code } & \multicolumn{1}{c}{ Land Use Designation } & Consolidated Land Use Designation \\
\hline C & Commercial & \\
HI & Heavy Industrial & \\
LI & Light Industrial & Commercial/Industrial \\
0 & Office & \\
PS & Public Service & \\
PU & Public Utility & Institutional \\
\hline IN & Institutional & Open/Undeveloped \\
\hline PR & Parks \& Recreation & \\
VA & Vacant & \\
\hline CH & Congregate Housing & \\
ED & Educational & Residential \\
MF & Multi Family & \\
MH & Mobile Home & \\
MU & Mixed Use & \\
SF & Single Family & \\
TF & Two Family & \\
ROW & Right of Way &
\end{tabular}


Table 6 Project land use area distribution.

\begin{tabular}{lcc}
\hline \multicolumn{1}{c}{ Land Use } & Area (Acres) & $\%$ of Total \\
\hline Residential & 1658 & $45 \%$ \\
Commercial/Industrial & 831 & $22 \%$ \\
Institutional & 154 & $4 \%$ \\
Open/Undeveloped & 265 & $7 \%$ \\
Right of Way & 798 & $22 \%$ \\
Total & 3706 & - \\
\hline
\end{tabular}

Using the data from the NSQD, final EMCs for TSS and $\mathrm{CBOD}_{5}$ were developed for each land use category as shown in Table 7. Using these concentrations, separate area weighted EMC values were determined for each tributary combined or stormwater area.

Table 7 Median pollutant concentrations.

\begin{tabular}{|c|c|c|c|c|c|}
\hline $\begin{array}{c}\text { Consolidated Land Use } \\
\text { Designation }\end{array}$ & $\begin{array}{l}\text { TSS Range }^{(1)} \\
(\mathrm{mg} / \mathrm{L})\end{array}$ & $\begin{array}{l}\text { TSS Median }^{(1)} \\
(\mathrm{mg} / \mathrm{L})\end{array}$ & $\begin{array}{c}\mathrm{BOD}_{5} \\
\text { Range }^{(1)} \\
(\mathrm{mg} / \mathrm{L})\end{array}$ & $\begin{array}{c}\mathrm{CBOD}_{5} \\
\text { Median }^{(2)} \\
(\mathrm{mg} / \mathrm{L})\end{array}$ & Source \\
\hline Residential & $3-2462$ & 49 & $0.1-433.4$ & 7 & $\begin{array}{l}\text { NSQD Residential. } \\
\text { Average of NSQD }\end{array}$ \\
\hline Commercial/Industrial & $3-2490$ & 62 & $0.1-270$ & 8 & $\begin{array}{l}\text { Commercial and } \\
\text { Industrial. }\end{array}$ \\
\hline Institutional & $5-76$ & 17 & $1-53.8$ & 7 & NSQD Institutional. \\
\hline Open/Undeveloped & $3-980$ & 49 & $1-24$ & 4 & NSQD Open Space. \\
\hline
\end{tabular}

Pollutants were then routed from their contributing source to the stream via wet weather flows generated from storm events, which was done by combining EMCs with flow rates to develop loadings. A schematic of the loading inputs and relationship to the reaches is presented in Figure 2.

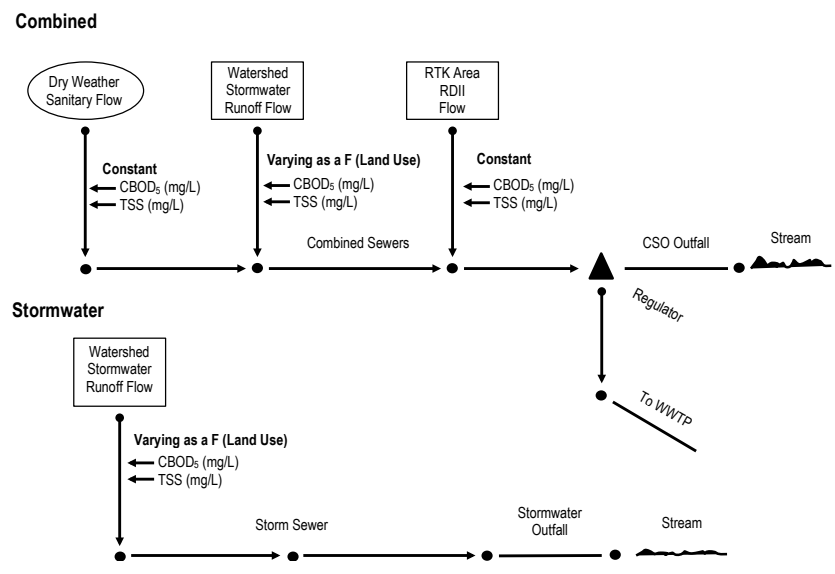

Figure 2 Example pollutant loading generation schematic.

RDIl enters the sewer system through direct and indirect sources such as footing drain connections, leaky manholes and pipe joints. RDIl at various levels contributes flow to sanitary, storm and combined sewer systems.

Limited data is available for determining pollutant concentrations associated with RDII. Generally, the water quality associated with RDII is anticipated to have lower pollutant levels than stormwater runoff (pollutants may be filtered out through the soil). For this study, engineering judgment was applied in conjunction with data from similar projects that were used to estimate pollutant loadings from RDII sources as part of the City of Detroit's long term CSO program (City of Detroit 2011). Table 8 shows the RDIl pollutant concentrations that were assumed for TSS and $\mathrm{CBOD}_{5}$ as part of this analysis.

Table 8 RDII pollutant load concentrations.

\begin{tabular}{rcc}
\hline Description & $\mathrm{TSS}(\mathrm{mg} / \mathrm{L})$ & $\mathrm{CBOD}_{5}(\mathrm{mg} / \mathrm{L})$ \\
\hline Wet Sanitary RDII Flow & 45 & 5 \\
\hline
\end{tabular}

\section{Summary of Pollutant Event Mean Concentrations}

Table 9 provides a summary of all the pollutant load sources and their corresponding event mean concentration.

Table 9 Summary of pollutant even mean concentrations.

\begin{tabular}{lcc}
\hline \multicolumn{1}{c}{ Pollutant Source } & TSS $(\mathrm{mg} / \mathrm{L})$ & $\mathrm{CBOD}_{5}(\mathrm{mg} / \mathrm{L})$ \\
\hline Sanitary Base Flow & 233 & 100 \\
RDII & 45 & 6 \\
\hline Stormwater Runoff & & \\
Commercial \& Industrial & 62 & 10 \\
Institutional & 17 & 9 \\
Open Space & 49 & 5 \\
Residential & 49 & 9 \\
\hline
\end{tabular}

\section{Loading Pollutants into SWMM5}

The first step for all sources of the pollutant loading is to develop the pollutant within the model. To begin, open SWMM5's Pollutant Editor and define the pollutants of concern, which in this case are TSS and $\mathrm{CBOD}_{5}$. Because RDIl and sanitary base flow only contain a single EMC, their concentrations can be defined directly in the pollutant editor.

Stormwater runoff EMCs are dependent upon the land use from which the runoff originates. Open the Land Use Editor to define these parameters, leaving all values within the General tab set to a value of zero.

Once all the land uses are defined, a rate at which pollutants accumulate on each of the different land uses needs to be assigned. In the Buildup tab of the land use editor, assign a high max. buildup and rate constant relative to the washoff rate (discussed below) to ensure that an abundance of pollutant is loaded to each subcatchment. This high buildup rate ensures that pollutant will not run out during a wet weather event.

With all the subcatchments now loaded with pollutants, the rate at which each pollutant washes off during a wet weather event needs to be assigned for each land use. In the Washoff tab of the land use editor, set the coefficient equal to the corresponding EMC for the relevant land use as defined in Table 9. Setting the coefficient equal to one will prevent the washoff rate from decaying over time and ensure that the EMC is maintained for the duration of the wet weather event. 
With the pollutant loads assigned to the sanitary base flow, and RDII and tributary stormwater runoff based on land use, the pollutants will be properly routed through the collection system arriving at the treatment facilities for pollutant removal.

\subsection{Pollutant Removal Approach}

The following is a description of the various simplified pollutant removal approaches that were implemented in the pollutant load modeling simulations. To provide a quantitative determination of various technologies on pollutant removal, treatment effectiveness percentages were assigned to various CSO and stormwater treatment facilities.

\section{CSO Regulator Improvements}

The reduction of CSO and pollutant loads can be achieved by increasing the capacity of existing CSO regulators to accept more wet weather flows. This technology is applied in each of the alternatives. Pollutants conveyed through a CSO regulator to the WWTP were assumed to be $100 \%$ captured.

\section{Sewer Separation}

Sewer separation reduces pollutant loadings by preventing the high pollutant concentration sanitary base flow waste stream from mixing with wet weather stormwater flows. Once storm flows are separated, only the pollutant loading associated with the stormwater passes directly into the stream. Sewer separation diverts a higher percentage of sanitary flow to the WWTP by freeing conveyance capacity that was otherwise occupied by stormwater. If stormwater treatment facilities are included within the new stormwater system, further pollutant removal can be achieved.

\section{CSO Storage Tanks}

Storage tanks are offline CSO facilities that operate by providing capture of overflow up to a specific tank volume. After the tank is filled, no additional flow or pollutant load can be captured. After the storm, the volume that is captured within the storage tank is eventually dewatered back to the collection system when capacity is available for treatment at the WWTP. The stored volume results in $100 \%$ capture of TSS and $\mathrm{CBOD}_{5}$ loadings within the tank.

\section{General Treatment Facility Considerations}

Treatment facilities include conventional stormwater detention ponds, bioretention ponds, constructed wetlands as well as EHRT facilities for CSO treatment. Although the treatment efficiency rates may vary, each facility operates on the same principle of providing a reduction in pollutant concentration as the flow passes through the facility. Facilities may treat up to $100 \%$ of the flow or only provide treatment up to a maximum flow rate while any additional flow bypasses. Figure 3 depicts both treatment configuration scenarios with example calculations representing residential land use stormwater concentrations of TSS and a basin treatment efficiency of $70 \%$.
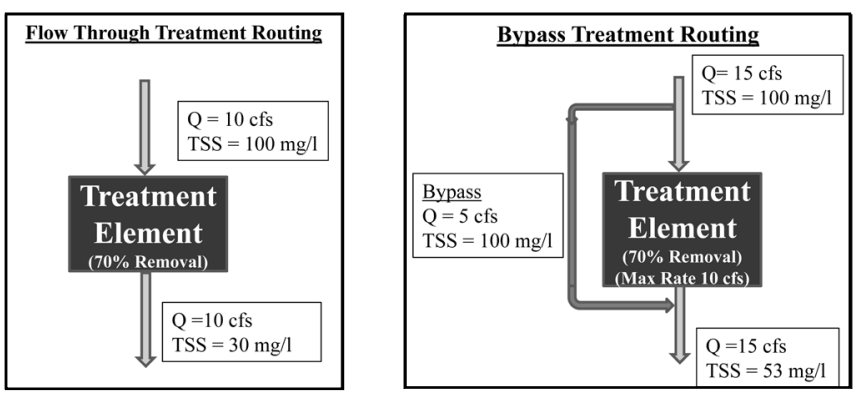

Figure 3 Pollutant removal through treatment basin schematic.

Treatment facilities generally provide a higher degree of treatment efficiency at lower flow rates due to reduced velocity and longer settling times. Although it is possible to model treatment efficiency that is dependent on flow rate, the modeling for this project remained consistent with the use of EMCs for pollutant loading through the use of average pollutant removal rates at each basin.

\section{Enhanced High Rate Treatment Facilities}

An enhanced high rate treatment (EHRT) facility is specifically designed to treat and disinfect wastewater flows generated by wet weather up to a specific peak rate. EHRT facilities use advanced physical-chemical processes to treat wastewater instead of the biological processes used by more conventional wastewater treatment plants. This allows flows to be processed much more quickly. EHRT facilities operate only when needed, are much smaller than conventional treatment facilities and can more easily be designed to blend into the surrounding neighborhood.

Treatment of flows is accomplished by introducing chemicals that result in the precipitation of solids within a settling tank, followed by disinfection and dechlorination. The expected water quality treatment efficiency for the EHRT was assumed to be $70 \%$ for TSS and $35 \%$ for $\mathrm{CBOD}_{5}$. These values were developed based on engineering judgment in conjunction with "Alternative Operational Strategies to Control Pollutants in Peak Wet Weather Flows" (Melcer et al. 2005).

\section{Stormwater Ponds}

Stormwater detention ponds can be classified as either wet or dry. A wet stormwater detention pond includes a permanent pool of water for removing pollutants and additional capacity for detaining stormwater runoff. From a hydrologic perspective, these basins function when water in the permanent pool mixes with and dilutes the initial runoff from storm events. Wet detention basins fill with stormwater and slowly release the mixed flow over a period of a few days, allowing for sedimentation and biological uptake. Biological uptake is defined as the pollutant removal services resulting from the consumption of pollutants by plants, algae and bacteria in the water. Runoff generated during the early phase of the storm typically contains the highest sediment and dissolved pollutant concentrations. Because the stormwater basin dilutes and settles pollutants in the initial runoff, the concentration of pollutants in runoff released to the environment 
is reduced. Based on a review of the National Pollutant Removal Performance Database (Center for Watershed Protection 2007), Effectiveness Evaluation of Best Management Practices for Stormwater Management in Portland, Oregon (City of Portland 2006), An Evaluation of Cost and Benefits of Structural Stormwater Best Management Practices In North Carolina (Wossink and Hunt 2003) and applying engineering judgment based on experience, the assumed water quality treatment efficiency for stormwater basins in this evaluation was $80 \%$ for TSS and $50 \%$ for $\mathrm{CBOD}_{5}$.

\section{Emergent Stormwater Wetlands}

The open spaces contained in the sloping ravine areas within the watershed provided an opportunity to develop terraced wetland cells arranged in series to function as stormwater treatment and runoff volume attenuation devices. Emergent stormwater wetlands were selected as the source control method in several alternatives to reduce runoff flows and perform water quality enhancement services within the ravines upstream of specific CSO regulators. Placed along the bottom of the sloped ravines, these shallow terraced wetlands were designed to temporarily store stormwater runoff in shallow pools that predominantly comprises emergent wetland and riparian vegetation located at the sloping banks and upland transitions. The storage volume, complex microtopography and vegetative community in stormwater wetlands combine to form an ideal matrix for the removal of many pollutants.

Stormwater wetlands provide an efficient method for removing a wide variety of pollutants, such as suspended solids, nutrients, heavy metals, toxic organic pollutants, and petroleum compounds. The sedimentation process is facilitated by dense stands of vegetation that create the quiescent conditions that facilitate the physical, chemical and biological processes that cleanse runoff. The settled pollutants are consumed and transformed by plants and microbes, immobilized in sediment, and a small percentage is released in reduced concentrations in the wetlands' outflows. Many herbaceous wetland plants die annually. Because the dead plant material requires months or years to decompose, a dense layer of plant litter accumulates in the wetland. However, like the living vegetation, the litter creates a substrate that supports bacterial growth and physically traps solids. Long term monitoring data from wetland treatment systems indicates that treatment performance for parameters such as TSS and $\mathrm{CBOD}_{5}$ typically do not deteriorate over the life of a treatment wetland. Based on a literature review (Center for Watershed Protection 2007; City of Portland 2006; Wossink and Hunt 2003), expected water quality treatment efficiency for this stormwater control measure was assumed to be $80 \%$ for TSS and $50 \%$ for $\mathrm{CBOD}_{5}$.

\section{Bioretention Basins and Cells}

Bioretention is a stormwater source control that consists of a ground depression filled with a soil media mixture that supports various types of water-tolerant vegetation. The surface of the basin is protected from weeds, mechanical erosion and desiccation by a layer of mulch. Bioretention cells are most suited for use in densely developed urban settings with the characteristics of spatial constraints and highly impervious drainage areas. They can be used on small urban sites that would not normally support the hydrology of a wet detention pond and where the soils would not allow for infiltration devices. Bioretention cells are distributive stormwater controls that are shallow ( $<12$ in., $30.5 \mathrm{~cm}$, depth) bowls, located in landscaped open spaces in developed sites. Typically, they can be located in areas of the site such as parking islands and the edges of roadways. Because the size of the bioretention area is a function of the amount of impervious surfaces contributing to the catchment drainage area, larger impervious areas are serviced with a deeper depression or basin that is between $2 \mathrm{ft}, 61 \mathrm{~cm}$, and $4 \mathrm{ft}, 1.22 \mathrm{~m}$, deep and a soil mix infiltration area of $\geq 1.5 \mathrm{ft}, 46 \mathrm{~cm}$, and $\leq 4 \mathrm{ft}, 1.22 \mathrm{~m}$. For the above reasons, bioretention areas were selected as a stormwater source control for the urban tributary areas.

Bioretention basins and smaller scale bioretention cells are ideally deployed in an off line configuration (having the ability to bypass flow once the inflow begins to exceed the device capacity) to which initial stormwater flows are diverted. An overflow structure allows excess flow to bypass the basin or cell. Bioretention facilities need an underdrain system to accommodate the native soils when low infiltration rates occur due to saturation. A small forebay area is included in the conceptual design of the basins to trap sediments. The sediment forebay allows the water to pond and coarser sediment to settle out before entering the larger basin area. This prevents sediments from clogging the main infiltration area, which if allowed to occur unabated, would diminish the storage capacity and treatment efficiency of the main basin soil mix.

Based on literature review (Center for Watershed Protection 2007; City of Portland 2006; Wossink and Hunt 2003) and engineering judgment, pollutant removal efficiencies of the target pollutants for the bioretention areas are as shown in Table 10.

Table 10 Pollutant removal efficiencies.

\begin{tabular}{lcc}
\hline & TSS Pollutant Removal Rate & CBOD $_{5}$ Pollutant Removal Rate \\
\hline Bioretention Basin & $80 \%$ & $50 \%$ \\
Bioretention Cell & $50 \%$ & $25 \%$ \\
\hline
\end{tabular}

Summary of Estimated Pollutant Removal Efficiencies

Table 11 provides a summary of the estimated pollutant removal rates for each type of treatment facility.

Table 11 Summary of estimated pollutant removal efficiencies.

\begin{tabular}{lcc}
\hline \multicolumn{1}{c}{ Treatment Feature } & TSS & CBOD $_{5}$ \\
\hline CSO Regulator (flow directed to WWTP) & $100 \%$ & $100 \%$ \\
Sewer Separation (sanitary flow directed to WWTP) & $100 \%$ & $100 \%$ \\
Storage Tank (stored flow and then directed to WWTP) & $100 \%$ & $100 \%$ \\
EHRT & $70 \%$ & $35 \%$ \\
Stormwater Pond & $80 \%$ & $50 \%$ \\
Emergent Stormwater Wetland & $80 \%$ & $50 \%$ \\
Bioretention Basin & $80 \%$ & $50 \%$ \\
Bioretention Cell & $50 \%$ & $25 \%$ \\
\hline
\end{tabular}


Loading Pollutant Removal Features in SWMM5

Loading the EHRT into SWMM5 will be used as an example, but all pollutant removal features are loaded in a similar manner. Select the node through which flow is being routed for treatment and open the Treatment Editor. Because a simplified constant removal rate is being assigned, the simplified $R$ (= fractional removal) should be assigned to each pollutant's treatment expression.

Pollutant loaded flow routed through the EHRT will now show a reduction in TSS and $\mathrm{CBOD}_{5}$ of $70 \%$ and $35 \%$, respectively, before being discharged to the receiving stream. An example of this can be seen in Figure 4. Flow can be seen entering the basin up to the treatment capacity of the EHRT during a wet weather event on the top half of the plot. TSS concentration is shown on the bottom half of the plot with a higher concentration for the influent flow and approximately a 70\% reduction in TSS for the effluent flow. Other treatment facilities will operate in a similar manner.

\section{Results and Conclusions}

\subsection{Design Storm Selection}

For this analysis, two wet weather storm scenarios were selected to evaluate the relative impact of CSO alternatives on water quality: a single event and a continuous period of precipitation. First, a single design storm with a total rainfall volume of $0.75 \mathrm{in}$.
(19 $\mathrm{mm}$ ) was selected for use in generating single event pollutant loads. This storm is commonly referred to by the OEPA as the water quality volume event and is representative of the amount of volume of runoff for a typical storm (OEPA, 2003).

The second storm scenario consisted of annual simulation of rainfall referred to as the typical year. This rainfall consisted of an entire year of rainfall that was determined to be the statistical average rainfall pattern that could be expected for the region annually based on eight parameters: 1) mean number of events, 2) average event volume, 3) duration, 4) intensity, 5) inter-event time, 6) days with rain, 7) hours of rain, and 8) annual volume of rain. Based on a rain gauge selection examination, data from a single rain gauge station located at the CVG Airport were used for the typical year analysis for the period from 1949 to 1992 (CH2M Hill and Vieux \& Associates, Inc. 2013). Per the District modelling standards, a modelling time step of one hour was used for the typical year simulation (XCG Consultants, Inc. 2013).

\subsection{Results}

Figures 5 and 6 present the results for the $0.75 \mathrm{in}$. (19 $\mathrm{mm}$ ) storm event and the typical year simulations respectively. Each figure represents the total pollutant load conveyed to the receiving stream in pounds. The difference in pollutant load from the existing conditions to the alternatives represents the reduction in pollutant load that was achieved.

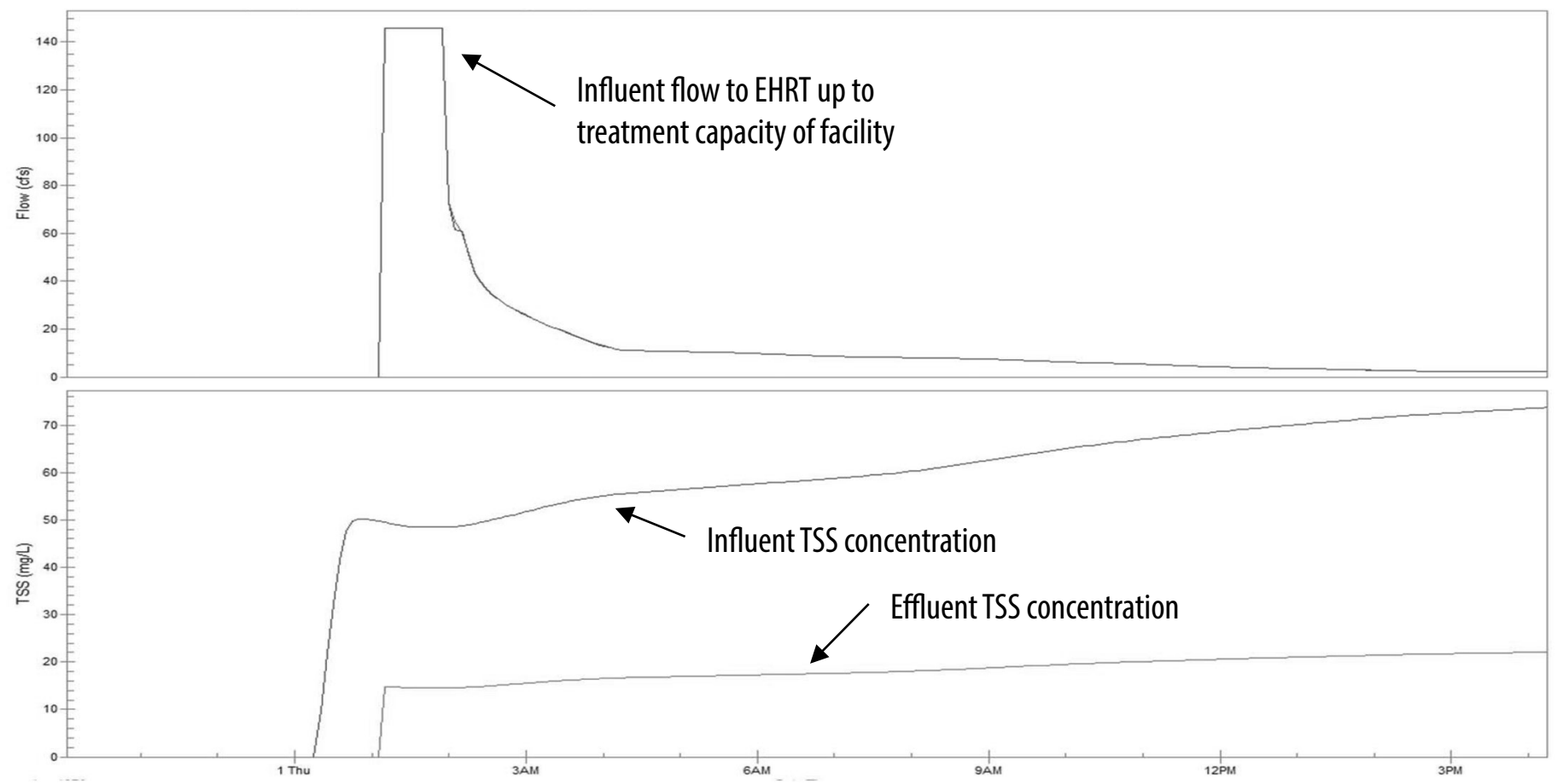

Figure 4 Example SWMM5 pollutant reduction plot for EHRT. 


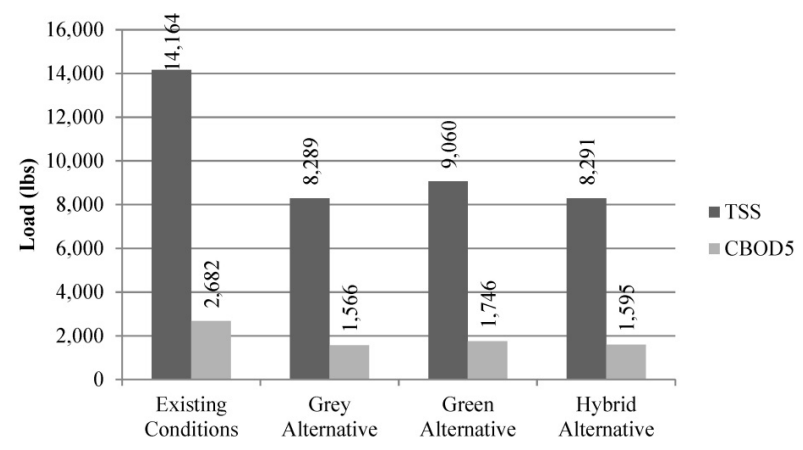

Figure 50.75 in. design storm pollutant loading to the receiving stream.

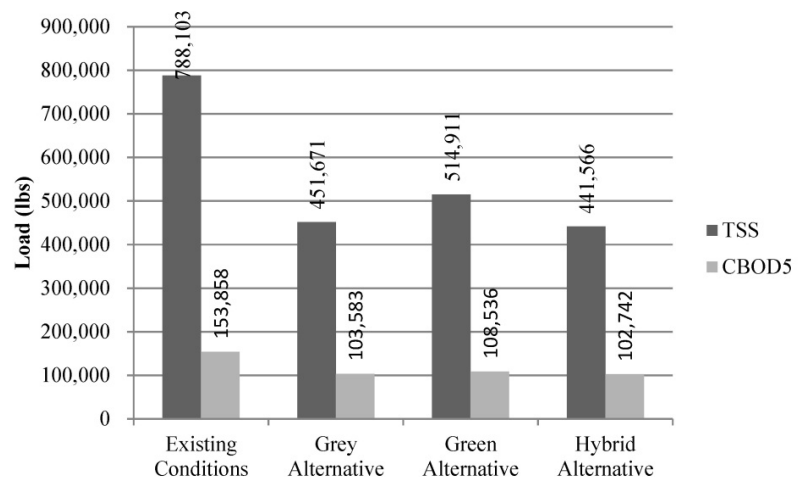

Figure 6 Typical year simulation pollutant loading to the receiving stream.

The results from the typical year simulations are based on annual loads from all typical year rain events rather than a discrete design storm event and include significantly more total pollutant load. The existing conditions results represent the existing pollutant load to the stream without any project improvements, and is the baseline condition against which all other model results are measured. The green alternative results show less pollutant removal than the other alternatives, because a portion of the separated stormwater flow is not passing through a stormwater treatment facility (which would provide pollutant removal). A comparison of the total area of separation done for each alternative and how much of that sewer separation was routed through a stormwater treatment facility is provided in Figure 7.

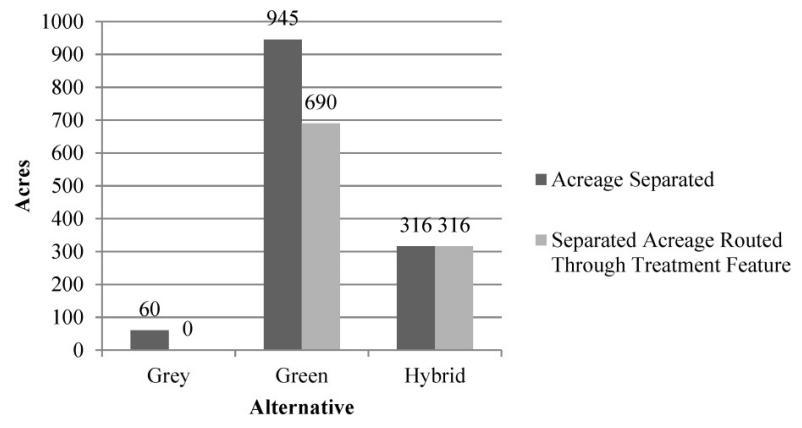

Figure 7 Comparison of total acres of separation and pollutant removal per alternative.

\subsection{Conclusions}

The approach taken allows for the analysis to consider the source of the pollutants as they originate in the upstream portions of the watershed and are subsequently routed through the system. Routing of pollutants through the system accurately simulates the mixing of the comingled flows and their resultant pollutant loads before arriving at the treatment facility and discharging to the stream. Using this approach for the existing conditions and across all alternatives allows for a relative comparison to determine which alternative provides the highest pollutant load reduction, as well as an estimate of the pollutant load reduction that can be expected when compared to the existing conditions baseline. Using this simplified approach negates the need for a robust data sampling program and minimizes engineering costs when conducting a CSO improvement alternatives screening process.

Based solely on TSS and $\mathrm{CBOD}_{5}$ as pollutants of concern, the results suggest the following conclusions:

1. Green and grey treatment facilities provide similar pollutant load reduction benefits; and

2. Sewer separation without treatment does not effectively reduce pollutant loadings to the stream.

\section{References}

Center for Watershed Protection. 2007. National Pollutant Removal Performance Database. 3rd edn. Ellicott City, MD: Center for Watershed Protection.

$\mathrm{CH} 2 \mathrm{M}$ Hill and Vieux and Associates, Inc. 2013. Design Storm Analysis. Cincinnati, $\mathrm{OH}$ : Metropolitan Sewer District of Greater Cincinnati.

City of Detroit. 2011. Long Term CSO Program. Detroit, MI: City of Detroit.

City of Portland. 2006. Effectiveness Evaluation of Best Management Practices for Stormwater Management in Portland, Oregon. Portland, OR: City of Portland.

Jenkins, A. 2011 Summary of Little Miami Waste Water Treatment Plant Historical Data 2007 to 2010. Cincinnati, OH:

Maestre, A. and R. Pitt. 2005. The National Stormwater Quality Database, Version 1.1: A Compilation and Analysis of NPDES Stormwater Monitoring Information. Washington, DC: U.S. Environmental Protection Agency.

Melcer, H., S. Krugel, R. Butler, P. Carter and G. Land. 2005. “Alternative Operational Strategies to Control Pollutants in Peak Wet Weather Flows." Water Environment Federation Technical Exhibition and Conference, Washington, DC. doi:10.2175/1938647057838

MSDGC (Metropolitan Sewer District of Greater Cincinnati). 2009. Final Wet Weather Improvement Program. Cincinnati, $\mathrm{OH}$ : U.S. Environmental Protection Agency.

Muirhead, W. M., G. Farmer, S. Walker, L. Robb, H. Elmendorf, R. Matthews, R. Butler and H. Melcer. 2006. "Study of Raw 
Wastewater $\mathrm{BOD}_{5}$ and $\mathrm{CBOD}_{5}$ Relationship Yields Surprising Results." Water Environment Federation Technical Exhibition and Conference, Dallas, TX.

OEPA (Ohio Environmental Protection Agency). 2003. Guidance Regarding Post-Construction Storm Water Management Requirements of Ohio EPA's Storm Water Construction. General Permit \#OHC000002. Columbus, OH: OEPA.

OEPA (Ohio Environmental Protection Agency). 2010. Total Maximum Daily Loads for the Lower Little Miami River Watershed. Columbus, OH: OEPA.

Stahre, P. and B. Urbonas. 1993. Stormwater: Best Management Practices and Detention for Water Quality, Drainage, and CSO Management. Englewood Cliffs, NJ: Prentice Hall.
Wade Trim, Inc. and XCG Consultants, Inc. 2012. Task 207 Revised Model Validation Technical Memorandum. Cincinnati, $\mathrm{OH}$ : Metropolitan Sewer District of Greater Cincinnati.

Wossink, A. and B. Hunt. 2003. An Evaluation of Cost and Benefits of Structural Stormwater Best Management Practices in North Carolina. Raleigh, NC: North Carolina State University, North Carolina Cooperative Extension Service.

XCG Consultants, Inc. 2013. MSDGC Modeling Guidelines and Standards, Volume I: System Wide Model. Cincinnati, OH: Metropolitan Sewer District of Greater Cincinnati. 